$\ll$ Research Note»

\title{
Administration of Erythromycin dose not Stimulate Food Intake in Fasted Chickens
}

\author{
Ryuichi Ando ${ }^{1)}$, Takashi Bungo ${ }^{2)}$ and Mitsuhiro Furuse ${ }^{1)}$ \\ 1) Laboratory of Advanced Animal and Marine Bioresources, Graduate School of Bioresource \\ and Bioenvironmental Sciences, Ky ushu University, Fukuoka 812-8581, Japan \\ ${ }^{2)}$ Laboratory of Animal Science, Department of Agrobiological Science, Faculty of \\ Agriculture, Ehime University, Matsuyama 790-8566, Japan
}

Several neural peptides are known to stimulate feeding behavior in mammalian species. Among them, administration of motilin has been found to stimulate feeding behavior in rats and mice. However, central administration of mammalian motilin did not stimulate food intake of the neonatal chick in the previous study. Erythromycin acts as a smooth muscle motilin receptor agonist in mammals, but its effect on feeding behavior has not been investigated. The aim of this study was to elucidate whether administration of nonpeptidergic motilin agonist erythromycin stimulates feeding of fasted neonatal chicks. We administered ery thromycin through intraperitoneal and oral routes, since it acts on the gut. No significant effects on food intake were obtained after intraperitoneal and oral administration of erythromycin. We also used the growing (4 -week-old) chicken for oral administration of erythromycin, but no significant effect on food intake was obtained. These data suggested that erythromycin did not stimulate feeding in fasted chicks.

(Jpn. Poult. Sci., $37: 372-378,2000)$

Key words : erythromycin, feeding, chicken

\section{Introduction}

Some of the strongest evidence implicating the brain in the control of feeding comes from many studies by pharmacological (e.g., specific agonists of neurotransmitters and neuromodulators) and anatomical (e.g., destruction of the specific nucleus) treatments (CARLSON, 1994). Particularly, the hypothalamus has an important role for the regulation of food intake and many factors have been established up to the present. During the recent decade, many peptides are suggested to have a function as regulators of feeding behaviour (Flier and MARATOS-Flier, 1998).

Motilin is a 22-amino acid polypeptide secreted from the endocrine cells of the mucosa of the upper part of the small intestine (BRown et al., 1971). Motilin stimulates migrating motor complexes (MMC) especially in the antrum and upper duodenum, and it is widely acknowledged that motilin is involved in the regulation of interdigestive motility (LEE et al., 1983). MMC is a rhythmic diffusive contraction of the gut in a fasted phase. We thought that MMC, which comes from motilin, might be involved in the regulation of feeding behavior. In fact, motilin has noticed as a stimulant of food intake. Peripheral and central administrations of motilin have been found to stimu- 
late feeding behavior in rats (Garthwaite, 1985, Rosenfeld and Garthwaite, 1986). Recently, the fact that intracerebroventricular (i.c.v.) administration of motilin increases food intake in fasted mice has been demonstrated (AsAKAwa et al., 1998). In the previous study, we elucidated whether central injection of mammalian motilin stimulates feeding of neonatal chicks. However, food intake was not stimulated by central injection of porcine and canine motilin (ANDO et al., 2000). Then, we aimed at erythromycin, which is a potent stimulant of motor activity in the stomach and small intestine. In vitro studies show that erythromycin can specifically and reversibly displace radiolabeled motilin bound to intestinal smooth muscle preparations, suggesting that erythromycin acts as a smooth muscle motilin receptor agonist (KonDo et al., 1988). Erythromycin is a nonpeptidergic antibiotic and this point is largely different from the peptide hormone, motilin. If motilin was administered orally, it could be digested by digestive enzyme secreted by host animals themselves, but erythromycin can be survived in the gut. If so, erythromycin may stimulate feeding behavior and may be a useful drug for chicken production.

The aim of the present study was to elucidate whether intraperitoneal and oral administrations of ery thromycin stimulate food intake in the fasted chick. To express erythromycin-induced MMC, substitute for spontaneous MMC that occurs in fasted state, birds were deprived food for $3 \mathrm{~h}$ or $6 \mathrm{~h}$ and given the diet previous $10 \mathrm{~min}$ to treatments.

\section{Materials and Methods}

\section{Animals}

Day-old male broiler chicks were purchased from a local hatchery (Mori Hatchery, Fukuoka, Japan). Birds were maintained in a room with $24 \mathrm{~h}$ light and at a temperature of $28^{\circ} \mathrm{C}$. They were given free access to a commercial starter diet (Toyohashi Feeds and Mill Co. Ltd., Aichi, Japan) and water. The experimental conditions applied here such as room temperature, lighting, feeding conditions were selected because Furuse et al. (1997) confirmed that neuropeptide Y stimulates food intake of chicks in the same condition. Before each experiment, body weight was measured. The range of body weight $(\mathrm{g})$ in each experiment was as follows : 73-88 (79.6 \pm 0.66 (SEM)) in

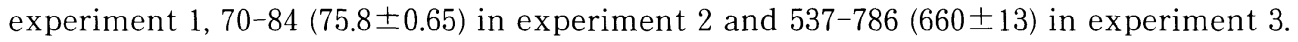
Chicks were distributed into experimental groups based on their body weight, so that the average body weight was as uniform as possible within the same experiment.

\section{Experiments}

Erythromycin was purchased from Sigma (St. Louis, MO, USA) and was dissolved in $0.85 \%$ saline. Birds (4-day-old) which deprived of food for $3 \mathrm{~h}$ and given the diet previous $10 \mathrm{~min}$ to treatments were administered intraperitoneally with four levels $(0$, $25,50$ and $100 \mu \mathrm{g} / 100 \mu \mathrm{l})$ of erythromycin in experiment 1 . In experiment 2 , birds $(3$ -day-old) were administered orally with four levels $(0,25,50$ and $100 \mu \mathrm{g} / 100 \mu l)$ of erythromycin under the same feeding condition as experiment 1. Birds (4-week-old) which deprived of food for $6 \mathrm{~h}$ and given the diet previous 10 min to treatments were injected intraperitoneally with two levels $(0$ and $2 \mathrm{mg} / 150 \mu l)$ of erythromycin in 
experiment 3. The doses applied here were decided according to the report of the mammal (Ітон et al., 1984).

\section{Measuring of food intake}

Food intake was determined by measuring the disappearance of diet from the pre-weighed feeder. The weight of feeders was weighed by using an electric digital balance of precision $\pm 1 \mathrm{mg}$.

\section{Statistical analysis}

Data wcre subjected to one-way ANOVA by the General Linear Model procedure using a commercially available package (SAS, 1985). The results were indicated as the mean \pm SEM.

\section{Results and discussion}

In the preliminary experiment, we applied four levels $(0,25,50$ and $100 \mu \mathrm{g} / 100 \mu \mathrm{l})$ of ery thromycin under ad libitum feeding. However, three level $(25,50$, and $100 \mu \mathrm{g} / 100 \mu l)$ of erythromycin did not alter food intake compared with the saline control. Thus, we administered intraperitoneally with four levels $(0,25,50$ and $100 \mu \mathrm{g} / 100 \mu l)$ of ery thromycin to the $3 \mathrm{~h}$ fasted chick in experiment 1 , since the fact that i.c.v. administration of motilin increases food intake in fasted mice has been demonstrated (AsAKAWA et al., 1998). As shown in Fig. 1, food intake of the chick that administered intraperitoneally with three levels of ery thromycin in the fasted state was not altered compared with the saline control. Thereupon, we administered orally with same levels (as experiment 1)

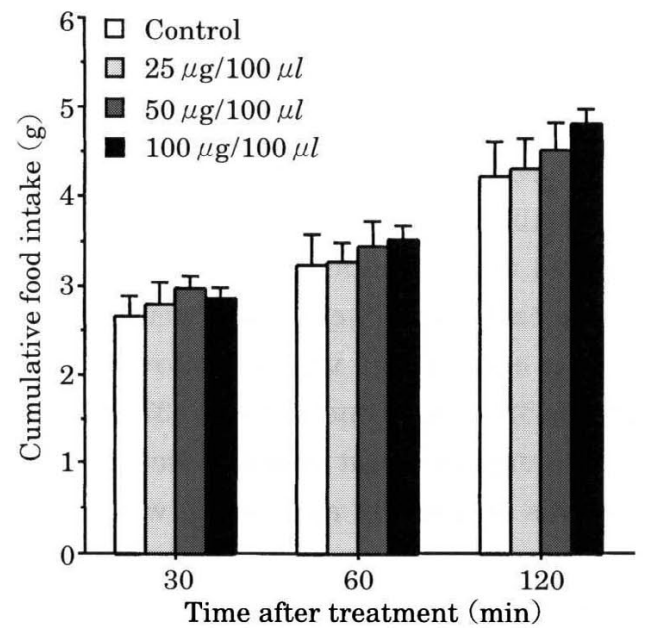

Fig. 1. Cumulative food intake of chicks administered saline or erythromycin $(25,50$ or $100 \mu \mathrm{g} / 100 \mu \mathrm{l})$ intraperitoneally. Birds deprived of food for $3 \mathrm{~h}$ were given the diet previous $10 \mathrm{~min}$ to treatments. Values are means \pm S. E. M. No significant effects were detected at any time determined. The number of birds used was; control, 7 ; $25 \mu \mathrm{g}, 7$; $50 \mu \mathrm{g}, 7$; and $100 \mu \mathrm{g}, 7$. 
of erythromycin to the chick which deprived of food for $3 \mathrm{~h}$ and given the diet previous 10 min to treatments in experiment 2. Cumulative food intakes of all birds in experiment 2 were somewhat lower than those of experiment 1 and this may be due to the difference in ages. Food intake was not influenced by any doses of erythromycin as shown in Fig. 2. So far, the growing birds (more than 4-week-old) have been used in the studies about the gastrointestinal motility in the chicken (Rodríguez-Sinovas et al., 1997, Clench and Mathias, 1992, Jiménez et al., 1994). In experiment 3, therefore, birds (4-week-old) which deprived of food for $6 \mathrm{~h}$ and given the diet previous $10 \mathrm{~min}$ to treatments were injected intraperitoneally with two levels $(0$ and $2 \mathrm{mg} / 150 \mu \mathrm{l})$ of erythromycin. As shown in Fig. 3, there was no significant effect on food intake after administration of erythromycin.

KiTAZAWA et al. (1997) reported that three erythromycin derivatives (EMA, EM523 and GM611) showed only a weak contractile efficacy (about $20 \%$ of the maximum response of chicken motilin) even at high concentration $(10-100 \mu \mathrm{M})$ in the chicken (aged 15-25 days) ileum. The rank order of potency in the chicken ileum was chicken motilin $>$ canine motilin $\geq$ Leu $^{13}$ porcine motilin $>>$ GM611 $\geq$ EM523 $\geq$ EMA. It seems likely that affinity of erythromycin for motilin receptor is low in avian species compared with mammals. It has been confirmed that single amino acid in the receptor structure can change the effectiveness of non-peptide antagonist (BEINBORN et al., 1993). This may be true for the non-peptide agonist such as erythromycin. The fact indicates that motilin receptor may be somew hat different between mammalian and avian species.

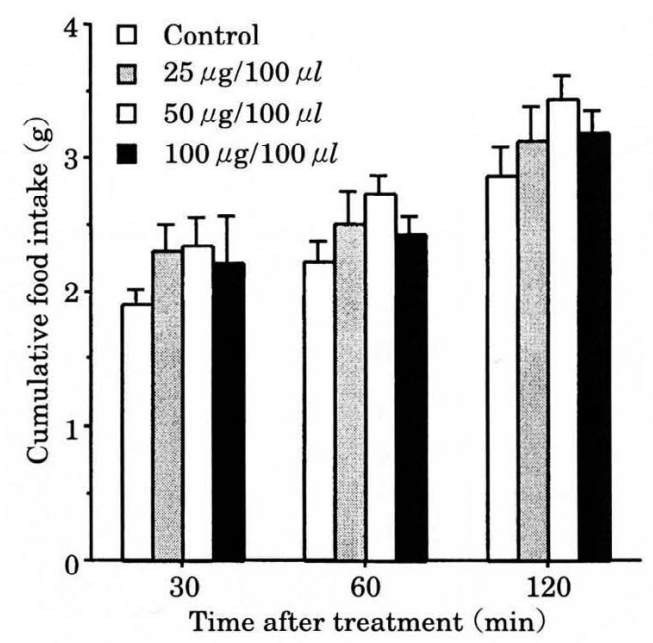

Fig. 2. Cumulative food intake of chicks administered saline or erythromycin $(25,50$ or $100 \mu \mathrm{g} / 100 \mu l)$ orally. Birds deprived of food for $3 \mathrm{~h}$ were given the diet previous $10 \mathrm{~min}$ to treatments. Values are means \pm S.E.M. No significant effects were detected at any time determined. The number of birds used was; control, $7 ; 25 \mu \mathrm{g}, 7$; $50 \mu \mathrm{g}, 7$; and $100 \mu \mathrm{g}, 7$. 


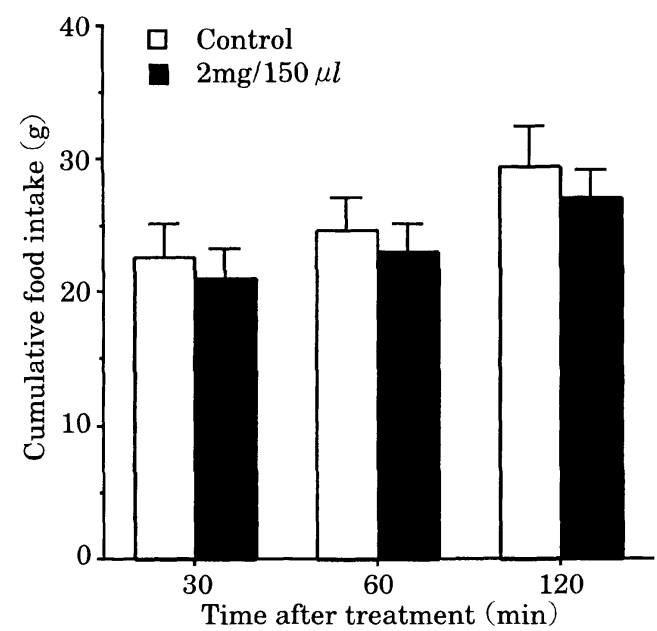

Fig. 3. Cumulative food intake of chicks administered saline or erythromycin $(2 \mathrm{mg} / 150 \mu \mathrm{l})$ intraperitoneally. Birds deprived of food for $6 \mathrm{~h}$ were given the diet previous $10 \mathrm{~min}$ to treatments. Values are means \pm S.E.M. No significant effects were detected at any time determined. The number of birds used was; control, $6 ; 2 \mathrm{mg}, 6$.

Collectively, data obtained here suggest that erythromycin is not a useful drug to enhance food intake of the chicken.

\section{Acknowledgement}

This study was supported by grant-in-aid for scientific research from the Ministry of Education, Science and Culture, Japan. Author (RA) appreciates to Japanese Poultry Science Association for making financial support to present this study at 21th World's Poultry Congress at Montreal Canada, September, 2000.

\section{References}

Ando, R., T. Bungo, S.-I. Kawakami, M. Shimojo, Y. Masuda and M. Furuse (2000) Intracerebroventricular injection of mammalian motilin, melanin-concentrating hormone and galanin does not stimulate food intake in neonatal chicks. British Poultry Science, in press.

Asakawa, A., A. Inui, K. Momose, K. Ueno, M.A. Fujino and M. Kasuga (1998) Motilin increase food intake in mice. Peptides, $19: 987-990$.

Beinborn, M., Y-M. Lee, E.W. Mcbride, S.M. Quinn and A.S. Kopin (1993) A single amino acid of the cholecystokinin-B/gastrin receptor determines specificity for non-peptide antagonists. Nature, 362: 348-350.

Brown, J.C., V. MutT and J.R. DRYBuRGH (1971) The further purification of motilin, a gastric motor activity stimulating polypeptide from the mucosa of the small intestine of dogs. Canadian Journal of Physiology \& Pharmacology, 48 : 399-405.

Carlson, N.R. (1994) Ingestive behavior : Eating. In : Physiology of Behavior. 5th ed. pp. 395-429. Allyn and Bacon, London.

Clench, M.H. and J.R. Mathias (1992) A complex avian intestinal motility response to fasting. American Journal of Physiology, 262 : G498-G504. 
FLIER, J.S. and E. MARATOS-Flier (1998) Obesity and the hypothalamus : novel peptides for new pathway. Cell, $92:$ 437-440.

Furuse, M., M. Matsumoto, R. Mori, K. Sugahara and S. Hasegaw a (1997) Influence of fasting and neuropeptide $\mathrm{Y}$ on the suppressive food intake induced by intracerebroventricular injection of glucagon-like peptide-1 in the neonatal chick. Brain Research, $764: 289-292$.

Garthwaite, T.L. (1985) Peripheral motilin administration stimulates feeding in fasted rats. Peptides, $6: 41-44$.

Itoh, Z., M. NakAya, T. Suzuki, H. Arai and K. W AKabayashi (1984) Erythromycin mimics exogenous motilin in gastrointestinal contractile activity in the dog. American Journal of Physiology, 247 : G688-G694.

Jiménez, M., V. Martinez, A. Rodríguez-Membrilla, A. Rodríguez-Sinovas, E. Goñalons and P. VERGARA (1994) Rhythmic oscillating complex : characterization, induction, and relationship to MMC in chickens. American Journal of Physiology, 266 : G585-G595.

Kitazawa, T., T. TAneike and A. Ohga (1997) Functional characterization of neural and smooth muscle motilin receptors in the chicken proventriculus and ileum. Regulatory Peptides, 71 : $87-95$.

Kondo, Y., K. TORII, S. Omura and Z. ITOH (1988) Erythromycin and its derivatives with motilin-like biological activities inhibit the specific binding of ${ }^{125} \mathrm{I}$-motilin to duodenal muscle. Biochemical and Biophysical Research Communications, $150: 877-882$.

LEE, K.Y., T. ChANG and W.Y. Chey (1983) Effect of rabbit antimotilin serum on moelectric activity and plasma motilin concentration in fasting dog. American Journal of Physiology, 245 : G547 - G553.

Rodríguez-Sinovas, A., M. Jiménez, P. DE ClercQ, T.L. Peeters and P. Vergara (1997) Rhythmic oscillating complexes in gastrointestinal tract of chickens: a role for motilin. American Journal of Physiology, 272 : G916-G922.

Rosenfeld, D.J. and T.L. Garthwaite (1986) Central administration of motilin stimulates feeding in rats. Physiology \& Behavior, $39: 753-756$.

SAS INSTITUTE INC. (1985) SAS User's Guide : Statistics (Cary, NC, SAS Institute, Inc.). 


\title{
エリスロマイシンの投与は絶食後のニワトリヒナの 摂食を刺激しない
}

\author{
安東竜一1)・豊後貴嗣2) ・古瀬充宏 ${ }^{1)}$ \\ 1) 九州大学大学院農学研究院生物資源環境科学府, 福岡市 812-8551 \\ 2) 愛媛大学農学部, 松山市 790-8566
}

モチリンの投与がラットおよびマウスの椇食を刺激す ることが発見されている。しかしながら，我々の前回の 研究では, 哺乳類のモチリンの中枢投与はニワトリヒナ の摂食を刺激しなかった。哺乳類において，エリスロマ イシンは平滑筋のモチリンレセプターにアゴニストとし て働き，胃腸の強収縮運動を引き起こす。しかし，椇食 行動における効果はまだ調査されていない。本研究の目 的は, 非ぺプチド性のモチリンのアゴニストであるエリ スロマイシンの投与が, 絶食後のニワトリヒナの摂食を 刺激するかどうかについて調査することである。胃腸の 強収縮運動は空腹期に起こるが，内因性の強収縮運動を 押さえるため, 絶食した後, 薬物投与 10 分前に餌を給与
した。エリスロマイシンが胃腸で働くことを考虑して, 腹腔（4 日歯： $25 ， 50$ および $100 \mu \mathrm{g} / 100 \mu l ）$ および経口 (3 日齢：25, 50 抢よび $100 \mu \mathrm{g} / 100 \mu \mathrm{l}$ ) の経路でエリスロ マイシンを 3 時間絶食したヒナに投与したが，いずれも 摂食量において有意な差は認められなかった。6時間絶 食した 4 週齚のニワトリヒナにもエリスロマイシン 2 $\mathrm{mg} / 150 \mu \mathrm{l}$ を経口投与したが，摂食量に有意差は認めら れなかった。上記の結果より，エリスロマイシンはニワ トリヒナの摂食行動を調節しない可能性が示唆された。

(家禽会誌, 37:372-378, 2000) キーワード：エリスロマイシン, 摂食, ニワトリ 